\title{
EDITORIAL
}

$\mathrm{A}^{\mathrm{S}}$ far as can be judged in a short time, Greece and Rome A seems to be receiving the recognition for which its founders hoped. But a journal which cannot yet afford to pay its contributors is not secure until its supporters help to fill its columns as well as to pay its bills. The editors have received most valuable and kindly aid from many quarters, but not much yet from that body for whom more than any Greece and Rome is intended. Schoolmasters and mistresses are very loath to write. If they think that their views on Cicero, for instance, are of no value because they never have had the leisure to study the subject thoroughly, they are forgetting the tested enthusiasm which has often enabled them to revive a voice, stilled for centuries, in ears not too predisposed to welcome it. Cicero must have a peculiar meaning for one who has fought the barbarians on his behalf; and we cannot afford to forgo the help of this tried and proved devotion.

\section{THE PRONUNCIATION OF LATIN}

Wr have received a reply to Dr. Alington's article unfortunately too late for the Press. It will appear in our next number, together with extracts from correspondence on the same subject.

\section{COMPETITION}

THE editors regret that they received no copy of the Latin Hexameters which could be judged worthy of the prize. A version from Eton began well, but halfway through collapsed badly. The other few copies received bore little resemblance to Latin Verse, save that undeniably they could be scanned. The next competition will take a new form. A prize of half a guinea is offered for an English composition in not more than 1,000 words. The subject is either a Roman journey from Rome to Athens, or a speech before the Senate in defence of Catiline. Competitors must be under 19 years of age on February 28, 1933, by which date the composition must reach the Joint Editor at the City of London School, E.C.4. Envelopes must be marked 'Essay'. The winning composition, if good enough, will be printed in the June number. 